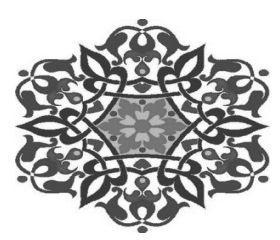

\title{
Pendidikan Karakter Anak Berbasis Al-Qur’an
}

\author{
Aas Siti Sholichah \\ Mahasiswi Program Doktoral Pendidikan Berbasis al-Quran \\ Institut PTIQ Jakarta
}

\begin{abstract}
Abstrak: Pendidikan karakter penting diberikan kepada anak-anak sejakdini, mengingatbanyakterjadipelanggaran dan dekadensi moral. Masalah yang terjadi seperti pencurian, tawuran, penyalahgunaan narkoba dan seks bebas, ini terjadi karena rendahnya perhatian orang tua dan lemahnya pendidikan karakter baik yang dilakukan keluarga, sekolah dan masyarakat. Upaya yang dapat dibangun untuk memperbaiki moral adalah melalui pembiasaan positif, tauladan dan komunikasi yang baik antar anak, orang tua dan pendidik. AlQur'an telah memberikan bimbingan pendidikan karakter melalui figur Lukmanul Hakim sebagai seorang ayah yang memberikan pendidikan kepada putranya dengan pendidikan tauhid, ibadah, hubungan sosial dan tadzkiyatunnafs yang terkandung di dalamnya pendidikan karakter tentang ketaatan, kesetiaan, disiplin, istiqamah, menghargai, toleransi, mencintai. Selain itu dalam Al-Quran juga memberikan uswatun hasanah melalui Rasulullah Muhammad SAW, yang mempunyai sifat sidiq (benar), amanah (terpercaya), tablig (menyampaikan dengan baik), fathanah (cerdas), yang dapat menjadi karakter setiap individu. Dengan penanaman pendidikan karakter sejak dini diharapkan dapat menciptakan soleh individu dan soleh secara sosial.
\end{abstract}

Kata Kunci: al-Qur'an, tadzkiyatunnafs, pendidikan, karakter

\section{A. Pendahuluan}

Mendidik anak di era digital saat ini memberikan tantangan yang sangat berat bagi orang tua dan pendidik. Pesatnya perkembangan teknologi telah membawa perubahan terhadap karakter dan gaya hidup setiap orang terutama 
anak-anak. Perubahan sikap dan perilaku anak-anak telah memberikan sumbangsih negatif bagi perkembangan karakter. Dari berbagai sumber yang ada menjelaskan bahwa telah terjadi berbagai ketimpangan karakter oleh remaja yang diakibatkan pola pendidikan karakter yang tidak diterapkan saat dini. Data menyebutkan bahwa seks bebas dikalangan remaja Indonesia mencapai 63\%. Data tersebut berdasarkan hasil survey dilakukan di 33 provinsi pada tahun 2008. Selain itu terjadi peredaran narkoba dengan jumlah korban sebanyak 1,1 juta orang. Perilaku menyimpang lainnya berdasarkan data Pusat Pengendalian Gangguan Sosial DKI Jakarta adalah tingginya tingkat tawuran yang dilakukan oleh pelajar SD, SMP dan SMA mencapai 1.318 siswa dari total siswa 1.647 .835 di DKI Jakarta. ${ }^{1}$

Globalisasi dan modernisasi juga memberikan dampak yang sangat signifikan. Terbukanya peluang dan kesempatan baik di bidang pendidikan, ekonomi, sosial dan budaya telah menghantarkan masyarakat pada kehidupan yang instan dengan mudahnya fasilitas yang tersedia. Kemudahan tersebut juga dapat dirasakan dalam bidang teknologi. Hasil dari teknologi canggih dapat menghantarkan kemudahan diberbagai aktifitas, sarana informasi seperti televisi hampir setiap rumah tersedia. Berbagai chanel dan tontonanpun begitu bebas bisa dipilih kapan saja dan dimana saja. Terlebih lagi dengan tersedianya internet yang menawarkan berbagai informasi dan layanan yang mudah dan menyenangkan. Karena mudahnya, seseorang tidak perlu keluar rumah untuk mendapatkan informasi. Dari dalam ruangan informasi seluruh dunia dapat diterima, apa yang terjadi di belahan dunia lain saat ini dapat dilihat langsung dari internet pada hampir saat yang bersamaan. Semua informasi tersedia dan mudah diakses dan dapat dibuka oleh semua umur begitu juga anak-anak.

Tontonan yang saat ini hadir di televisi sedikit nilai edukasi. Sinetron, iklan dan film tidak memberikan sumbangsih pendidikan kepada anak-anak. Film kartun yang menjadi tontonan anak-anakpun tidak lepas dari perilaku kekerasan. Berita yang disajikan-pun menampilkan berita kriminal yang cukup mengerikan. Film dan sinetron yang diputar mengandung pornografi dan pornoaksi yang tidak pantas ditonton anak-anak dan dewasa. Alur cerita film dan sinetron menggambarkan perilaku hedonis dan konsumtif yang jauh dari budaya Indonesia. Hal ini secara tidak langsung memberikan efek negatif terhadap karakter

\footnotetext{
${ }^{1}$ Data diperoleh dari berbagai sumber yang disarikan oleh Dharma Kesuma dll. Perilaku menyimpang lainnya adalah adanya pengangguran, terjadi KKN di berbagai lembaga dan kemiskinan yang terus meningkat mencapai 40 juta. Selain itu terjadi perilaku bullying yang melibatkan peserta didik. Terjadinya penyimpangan moral tersebut menurut Muhamad Takdir Ilahi dipengaruhi oleh orientasi pendidikan saat ini lebih mengedepankan pendidikan kognitif yang hanya mewajibkan setiap anak untuk mengetahui dan menghafal konsep dan kebenaran tanpa keterlibatan emosi, perasaan dan nurani. Dharmawan Kesuma, Pendidikan Karakter Kajian Teori dan Praktik Di Sekolah, (Bandung: Remaja Rosdakarya, 2013), cet-4, hal. 2-3.
} 
masyarakat Indonesia terutama anak-anak, karena mereka secara otomatis akan meniru dan mengikuti perilaku yang tidak sesuai dengan karakter bangsa Indonesia.

Selain itu aktifitas dan kesibukan orang tua terutama di kota besar telah mengalihkan perhatian dan pola asuh orang tua terhadap anak-anak. Kurangnya perhatian orang tua dan sedikitnya waktu bersama anak, memunculkan perubahan sikap dan perilaku anak-anak. Hal ini mengakibatkan anak melakukan perilaku yang tidak diinginkan.

Menurut data dari Komisi Perlindungan Anak Indonesia (KPAI) mencatat bahwa ada 229 kasus tawuran pelajar sepanjang Januari hingga Oktober tahun 2013, jumlah ini meningkat 44\% dari tahun 2012 dan sebanyak 19 siswa meniggal dunia. ${ }^{2}$ Melihat kenyataan yang miris tersebut, Ketua Komisi Perlindungan Anak Indonesia (KPAI) mengatakan bahwa tahun 2014 merupakan tahun darurat terhadap kekerasan anak ${ }^{3}$. Dalam situs resmi, KPAI merilis perkembangan sekaligus peningkatan angka tawuran pelajar selama satu dasa warsa yaitu bahwa perkelahian, atau sering disebut tawuran sering terjadi di kalangan pelajar, bahkan bukan hanya antar pelajar tapi sampai ke kampus-kampus. Ada juga yang mengatakan perkelahian antara pelajar adalah hal yang wajar. ${ }^{4}$

Survei nasional menunjukkan bahwa sebagian dari 10.000 peserta didik SMA mengaku pernah mencuri di pertokoan, dan tujuh dari sepuluh peserta didik mengaku menyontek saat ulangan dan penggunaan alkohol dan narkoba meningkat pada anak remaja sebanyak 22 persen. ${ }^{5}$

Rushwort Kidder, mengagendakan tujuh permasalahan penting pada abad 21 salah satunya adalah restrukturisasi sistem pendidikan, dimana sistem pendidikan yang dijalankan saat ini belum menyentuh dan menjawab persoalan-persoalan manusia. ${ }^{6} \mathrm{Hal}$ ini tidak hanya terjadi di negara-negara berkembang, negara-negara majupun mengalami hal yang sama.

Permasalahan tersebut sejalan dengan kondis riil kualitas pendidikan yang ada di Indonesia dimana data dari Balitbang menunjukkan bahwa dari

\footnotetext{
${ }^{2}$ http://www.kpai.go.id/artikel/tawuran-pelajar-memprihatinkan-dunia-pendidikan/ lihat pula situs tempo.co.id “Tawuran Sekolah Jakarta Naik 44 \%,. Diunduh pada tanggal 9 November 2014. vember 2014 .

${ }^{3}$ http://www. tempo.co.id “Tawuran Sekolah Jakarta Naik44”. Diunduh pada tanggal 9 No-

${ }^{4}$ http://www.kpai.go.id/artikel/tawuran-pelajar-memprihatinkan-dunia-pendidikan/ lihat pula situs tempo.co.id “Tawuran Sekolah Jakarta Naik,. Diunduh pada tanggal 9 November 2014.

${ }^{5}$ Michele Berba, Membangun Kecerdasan Moral (Jakarta: Gramedia Pustaka Utama, 2008), hal.2.

${ }^{6}$ Sudarto, Wacana Islam Progresif(Jogyakarta : IRCiSoD, 2014), hal. 131.
} 
146.052 Sekolah Dasar (SD) di Indonesia yang mendapat pengakuan dunia dalam kategori The Primary Years Program (PYP) hanya delapan sekolah Dasar. Dan dari 20.918 Sekolah Menengah Pertama yang ada di Indonesia, hanya delapan sekolah yang mendapatkan kategori The Middle Years Program (MYP) dan dari 8.036 jumlah Sekolah Menengah Atas (SMA) yang ada di Indonesia yang mendapat kategori The Diploma Program yaitu sebanyak tujuh sekolah. ${ }^{7}$

Fenomena kekerasan dan rendahnya mutu dalam dunia pendidikan menjadi masalah besar yang harus mendapatkan penanganan secara intensif, hal ini menjadi tanggug jawab bersama antar orang tua, guru, lembaga pendidikan dan steakholder dalam menemukan solusi tersebut.

Untuk mengantisipasi terjadinya dekadensi moral yang mengancam masa depan anak-anak, diperlukan upaya bersama untuk melakukan dan memberikan pendidikan karakter sejak usia dini. Perlunya pendidikan karakter anak adalah untuk mempersiapkan dan membentengi anak-anak terhadap arus globalisasi dan modernisasi negatif. Untuk itu diperlukan pola pemahaman yang menyeluruh baik orang tua, sekolah dan masyarakat.

Peran serta orang tua sangat menentukan perilaku dan karakter anakanak, karena pendidikan pertama adalah dari rumah yang dilakukan oleh orang tua. Untuk itu orang tua harus mempunyai visi bersama untuk membesarkan dan mendidik anak-anak dengan menjadikan pendidikan karakter sebagai landasan dengan diselaraskan dengan kemampuan kognitif, afektif dan psikomotorik anak.

Al-Qur'an sebagai landasan dan pijakan dalam mengatur kehidupan, di dalamnya juga memberikan pemahaman mengenai pendidikan karakter kepada anak-anak sebagaimana telah dicontohkan oleh Nabi Ibrahim dan Luqman. Untuk itu dalam penulisan ini penulis ingin mendapatkan informasi mengenai pendidikan karakter dalam Al-Qur'an dengan melakukan pendekatan penafsiran. Sehingga diharapkan dapat memberikan sumbangsih dalam memperbaiki pendidikan karakter anak.

\section{B. Diskursus Pendidikan Karakter Anak}

Dalam ajaran Islam, salah satu istilah yang mewakili pengertian pendidikan adalah al-tarbiyah. Kata at-tarbiyyah berasal dari kata rabb yang berarti membina/menumbuhkan sesuatu setahap demi setahap hingga mencapai batas

${ }^{7}$ Edi Junaedi Sastradiharja, Makalah Manajemen Peningkatan Mutu Berbasis Sekolah, hal. 1. 
yang sempurna. ${ }^{8}$ Kata at-tarbiyyah, yang berkaitan dengan pendidikan dapat ditemukan dalam Al-Qur'an surat Ali- Imran [3] 79 sebagai berikut:

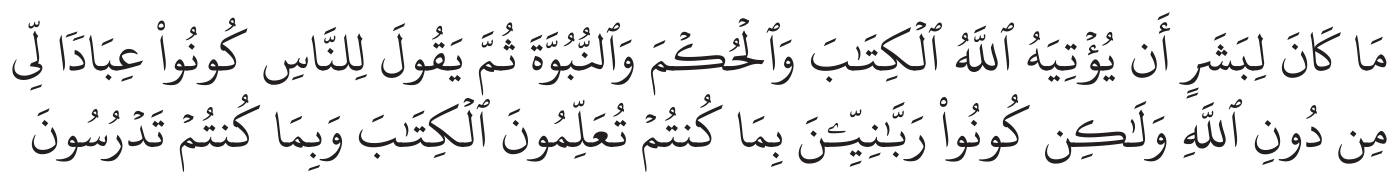

Tidak wajar bagi seseorang manusia yang Allah berikan kepadanya Al Kitab, hikmah dan kenabian, lalu dia berkata kepada manusia: "Hendaklah kamu menjadi penyembah-penyembahku bukan penyembah Allah". Akan tetapi (dia berkata): "Hendaklah kamu menjadi orang-orang rabbani, karena kamu selalu mengajarkan Al Kitab dan disebabkan kamu tetap mempelajarinya.(QS Ali 'Imran [3] 79).

Kata rabbânî mengandung pengertian orang yang sempurna ilmu dan takwanya kepada Allah SWT. Rabbânî adalah orang-orang yang memiliki ilmu pengetahuan yang sempurna yang terpanggil untuk mengajarkan ilmu dan kemampuan wawasan pengetahuan untuk disebarkan kepada masyarakat, dalam makna sederhana kata rabbânî dapat diartikan sebagai pengajar atau pendidik. ${ }^{9}$

Dari penjelasan di atas makna rabbânî yang disandarkan kepada pendidik memberikan makna kesempurnaan sikap dan sifat juga ilmu pengetahuan untuk setiap orang yang terpanggil hatinya menjadi pendidik. Untuk itu dalam pendidikan untuk mencapai keberhasilan pengajaran dan bimbingan maka diperlukan berbagai pendekatan baik itu yang berkaitan dengan kognitif, afektif maupun psikomotorik. Pedekatan ini dikenal dengan teori taksonomi Bloom. ${ }^{10}$ Ranah kognitif adalah ranah pembelajaran yang menggunakan aktifitas otak atau berfikir yang berorientasi pada pengembangan intelektual yang di dalamnya mengandung aspek pengetahuan, pemahaman, penerapan, analisis dan sintetis. Sedangkan ranah psikomotorik adalah kegiatan pembelajaran yang berorientasi pada skill atau kemampuan. Sedangkan ranah afektif adalah proses pembelajaran yang berorientasi pada sikap dan nilai, seperti perasaan sikap, emosi, dan nilai.

Selain pandangan mengenai pendidikan yang disampaikan di atas, berikut ini akan dikemukakan berbagai hakikat pendidikan yang disampaikan para tokoh pendidikan dengan bertujuan memberikan pemahaman dan kesadaran

\footnotetext{
${ }^{8}$ Menurut al-Raghib al-Asfahaniy "Tarbiyyah huwa insya al-syai halan fa halan ila had altamam. (Menumbuhkan/ membina sesuatu setahap demi setahap hingga mencapai batas yang sempurna). Disarikan oleh Abuddin Nata, Pendidikan dalam Perspektif Al-Quran (Jakarta: UIN Jakarta Press, 2005), hal. 90.

${ }^{9}$ Abuddin Nata, Pendidikan dalam Perspektif Al-Qur'an, hal. 92.

${ }^{10}$ W.S. Winkel, Psikologi Pengajaran (Jakarta: Gramedia, 1987), hal. 149.
} 
arti pentingnya pendidikan bagi setiap individu, baik pendidikan formal, nonformal dan informal.

Menurut John Dewey pendidikan adalah proses pembentukan kecakapan-kecakapan fundamental secara intelektual dan emosional ke arah alam dan sesama alam. ${ }^{11}$ Jhon Dewey merupakan merupakan tokoh pembaharu pendidikan abad 20, konsep pendidikan beraliran pendidikan progresif, dimana menempatkan pendidikan terpusat pada anak agar pengetahuan terorganisasi dipelajari demi tujuan-tujuan lain yang lebih besar. ${ }^{12}$

Sedangkan pendidikan menurut Ivan Illich adalah proses memberikan manusia berbagai macam situasi yang bertujuan memberdayakan diri dengan mempertimbangkan aspek penyadaran, pencerahan, pemberdayaan dan perubahan perilaku. ${ }^{13} \mathrm{Hal}$ ini memberikan isyarat perlunya mempersiapkan generasi yang dapat menciptakan peluang kerja dengan berbagai keterampilan dan pengetahuan yang dimiliki dengan tetap menjadikan pendidikan moral sebagai prioritas.

Sedangkan menurut Ahmad D. Marimba dalam buku Dasar-dasar Ilmu Pendidikan mendefinisikan pendidikan sebagai bimbingan atau pimpinan secara sadar oleh si pendidik terhadap perkembangan jasmani dan rohani si terdidik menuju terbentuknya kepribadian yang utama. ${ }^{14}$ Definisi tersebut, menjelaskan bahwa perlunya melakukan pendidikan yang berkaitan dengan aspek jasmani (fisik) dan rohani (psikis) sehingga dengan pendidikan jasmani dan rohani yang seimbang akan menghasilkan generasi yang cerdas intelektual serta soleh spiritual.

Ki Hajar Dewantara mendefinisikan pendidikan yaitu menuntun segala kekuatan kodrat yang ada pada anak-anak agar mereka sebagai manusia dan sebagai anggota masyarakat dapatlah mencapai kemaslahatan dan kebahagiaan setinggi-tingginya. ${ }^{15}$ Dalam makna yang lebih luas, ungkapan Ki Hajar Dewantara mengenai pendidikan juga dapat di definisikan sebagai penuntun, pembimbing, dan petunjuk arah bagi para peserta didik agar mereka dapat tumbuh menja-

69.

${ }^{11}$ Abu Ahmadi, dan Nur Uhbiyati, Ilmu Pendidikan (Jakarta: Rineka Cipta, 2000), hal.68-

${ }^{12}$ Nurani Soyomukti, Teori-teori Pendidikan (Yogyakarta: Ar-Ruzz Media, 2011), hal. 3233.

${ }^{13}$ Ivan Illich berpendapat bahwa sistem pendidikan yang baik harus mempunyai tiga tujuan, pertama memberikan kesempatan pada semua orang agar bebas dan mudah memperoleh sumber belajar pada setiap saat; Kedua, Memungkinkan semua orang mudah mengakses pendidikan; ketiga menjamin tersedianya masukan umum yang berhubungan dengan pendidikan. Nurani Soyomukti, Teori-teori Pendidikan,hal. 27 \& 32.

${ }^{14}$ Hasbullah, Dasar-dasar Ilmu Pendidikan (Jakarta: RajaGrafindo, 2001), hal. 3.

${ }^{15}$ Hasbullah, Dasar-dasar Ilmu Pendidikan. hal. 4. 
di dewasa sesuai dengan potensi dan konsep diri yang tertanam dalam diri sebenarnya. ${ }^{16}$

Berbagai hakikat definisi pendidikan di atas, sejalan dengan fungsi pendidikan menurut pasal 1 Undang-Undang Sistem Pendidikan Nasional Nomor 20 tahun 2003, fungsi pendidikan adalah mengembangkan kemampuan dan membentuk watak serta peradaban bangsa yang bermartabat dalam rangka mencerdaskan kehidupan bangsa. ${ }^{17}$ Upaya yang dilakukan dalam menciptakan tatanan kehidupan yang baik dan sejahtera diperlukan adanya sumber daya manusia yang unggul. Terciptanya sumber daya manusia unggul dapat teralisasi dengan adanya pola pendidikan yang baik yang dibangun bersama-sama antara pendidik, orang tua dan masyarakat dengan mengedepankan kemampuan intelektual, pembekalan keterampilan juga penanaman budi pekerti.

Jika diamati dari berbagai definisi pendidikan menurut berbagai tokoh pendidikan, penulis dapat mendefinisikan pendidikan sebagai usaha sadar dan terencana yang dilakukan oleh keluarga, sekolah, masyarakat dengan memberikan bimbingan, pengetahuan, keterampilan dan pembekalan budi pekerti yang bertujuan untuk menanamkan pengetahuan, keterampilan dan pembentukan watak kepribadian yang dapat menciptakan generasi yang dapat berdaya saing, cerdas intelektual dan soleh spiritual.

Sedangkan istilah karakter secara bahasa berasal dari bahasa Latin "Charakter", yang memiliki arti watak, tabiat, sifat-sifat kejiwaan, akhlak dan budi pekerti. Menurut Istilah karakter adalah sikap, tabiat, akhlak, kepribadian yang stabil sebagai hasil dari proses konsolidasi secara progresif dan dinamis. ${ }^{18}$

Menurut Amirullah Syarbini, pendidikan karkater adalah sifat yang mantap, stabil khusus yang melekat dalam pribadi seseorang yang membuatnya bertindak dan bersikap secara spontan, tidak dipengaruhi oleh kondisi dan tanpa memerlukan terlebih dahulu. ${ }^{19}$

${ }^{16}$ Menurut Ki Hajar Dewantara, pertama kali yang harus kita ingat bahwa pendidikan merupakan suatu tuntunan di dalam hidup, tumbuhnya anak-anak itu terletak di luar kecakapan atau kehendak kita kaum pendidik. Anak-anak itu sebagai makhluk, sebagai manusia, teranglah hidup sesuai kodratnya sendiri...yang dikatakan kekuatan kodrat yang ada pada anak-anak itu tiada lain ialah segala kekuatan di dalam hidup batin dan hidup lahir dari anak-anak itu, yang ada karena kekuasaan kodrat. Pendidik hanya dapat menuntun tumbuhnya kekuatan tersebut agar dapat memperbaiki lakunya. Disarikan oleh Dedi Mulyasana, Pendidikan Bermutu dan Berdaya Saing, (Bandung: Remaja Rosdakarya, 2012), hal. 5.

${ }^{17}$ Dedi Mulyasana, Pendidikan Bermutu dan Berdaya Saing, hal. 5.

${ }^{18}$ Yahya Khan, Pendidikan Karakter Berbasis Potensi Diri: Mendongkrak Kualitas Pendidikan (Yogyakarta: Pelangi Publishing, 2010), hal.1.

${ }^{19}$ Pengertian tersebut seperti yang di definisikan yang berniali baik dari seseorang. oleh Ibnu Maskawih merupakan upaya ke arah terwujudnya sikap bathin yang mampu mendorong secara spontan lahirnya perbuatan-perbuatan (Abudin Nata). Amirullah Syarbini, Buku Pintar Pendidikan 
Pendidikan karakter adalah upaya penanaman kecerdasan dalam berfikir, penghayatan dalam bentuk sikap, dan pengalaman dalam bentuk perilaku yang sesuai dengan nilai-nilai luhur yang menjadi jati diri yang diwujudkan dalam bentuk interaksi dengan Tuhan, diri sendiri, Masyarakat dan lingkungan. ${ }^{20}$

Michele Borba mengistilahkan pendidikan karakter dengan kecerdasan moral yang diartikan sebagai kemampuan memahami yang benar dan yang salah. Yaitu suatu sikap yang memiliki keyakinan etika yang kuat dan bertindak berdasarkan keyakinan tersebut sehingga dapat bersikap benar dan terhormat.

Definisi tersebut di atas seperti yang diungkapkan Albertus yang menjelaskan bahwa pendidikan karakter adalah diberikannya tempat bagi kebebasan individu dalam menghayati nilai-nilai yang dianggap sebagai baik, luhur dan layak diperjuangkan sebagai pedoman tingkah laku bagi kehidupan pribadi berhadapan dengan dirinya, sesama dan Tuhan. ${ }^{21}$

Karakter dibangun berdasarkan tiga komponen yaitu pengetahuan, sikap dan perilaku. Ketiga komponen ini tidak dapat dipisahkan karena masingmasing memiliki keterikatan. Pendidikan karakter dilakukan dengan contoh atau perlakuan bukan hanya sebatas teori. ${ }^{22}$

Untuk itu setiap orang tua, pendidik harus selalu berupaya untuk menanamkan karakter positif kepada setiap anak, sebagai bentuk sumbangsih dan tauladan baik melalui lisan, sikap dan praktek.

\section{Nilai-Nilai Dalam Pendidikan Karakter}

Pendidikan karakter merupakan satu bagian sikap yang bekerja secara integral, dimana sikap yang satu dengan sikap yang lain harus saling berkaitan. Sebagai contoh setiap perilaku memiliki konsekuensi, baik itu positif maupun negatif, hasil dari perilaku tersebut merupakan berkaitan dengan apa yang diungkapkan bagaimana sikap dan bagaimana tindakan dari perbuatan tersebut. Untuk itu perlu adanya nilai-nilai yang menjadi acuan sebagai bahan pelaksanaan pendidikan karakter.

Karakter: Panduan Lengkap Mendidik Karakter Anak di Sekolah, Madrasah dan Rumah (Jakarta: as@-Prima Pustaka, 2012), hal.17-18.

${ }^{20}$ Zubaedi, Desain Pendidikan Karakter: Konsepsi dan Aplikasinya dalam Lembaga Pendidikan (Jakarta: Kencana, 2011), hal. 17.

${ }^{21}$ Albertus, Doni Koesoema, Pendidikan Karakter Strategi Mendidik Anak di Zaman Global (Jakarta: PT. Grasindo, 2010), hal. 5.

${ }^{22}$ Ahmad Tafsir: Pendidikan Karakter Perspektif Islam (Jakarta: Remaja Rosda Karya, 2011), hal. Vi. 
Nilai-nilai yang terkandung dalam pendidikan karakter ini merupakan bagian kebaikan yang dapat diterima oleh siapa saja sebagai panduan dan acuan dalam pembentukan karakter. Selain itu Pembentukan karakter ini bersifat menyeluruh untuk kalangan dan rentang usia mana saja.

Untuk menciptakan Pendidikan karakter ini setiap orang dan kelompok/ lembaga memberikan sumbangsih pemikiran dan praktis. Dimana anggota parlemen (DPR) berupaya memasukkan pendidikan karakter ini sebagai kurikulum yang sekarang sudah disosialisasikan menjadi Kurikulum Tiga Belas. Lembaga sekolah dan dewan guru berupaya menanamkan pendidikan karakter melalui berbagai pendekatan yang dilakukan dalam pengajaran. Beberapa negara berupaya untuk memperkecil jumah murid dalam kelas dan meningkatkan standar akademis. Para psikolog mencoba mengembangkan teori-teori baru yang lebih lengkap seperti Daniel Goleman dengan teori kecerdasan emosi, Howard Gardner memberikan pemahaman tentang kecerdasan anak melalui kecerdasan majemuk. Upaya ini dilakukan merupakan bentuk tanggung jawab dan sumbangsih yang diberikan untuk perbaikan karakter.

Dalam Pasal 3 Undang-Undang Sistem Pendidikan Nasional nomor 20 tahun 2003 dijelaskan bahwa pendidikan nasional berfungsi mengembangkan dan membentuk watak serta peradaban bangsa yang bermartabat dalam rangka mencerdaskan kehidupan bangsa, bertujuan untuk berkembangnya potensi peserta didik agar menjadi manusia beriman dan bertaqwa kepada Tuhan Yang Maha Esa, berakhlak mulia, sehat, berilmu, cakap, kreatif, mandiri dan menjadi warga negara yang demokratis dan bertanggung jawab.

Sebagai manifestasi pelaksanaan Undang-undang Sistem Pendidika Nasional tersebut, Departemen Pendidikan Nasional mengembangkan 18 nilai-nilai pengembangan pendidikan budaya dan karakter. 18 nilai-nilai dalam pendidikan karakter tersebut yaitu religius, jujur, toleransi, disiplin, kerja keras, kreatif, mandiri, demokratis, rasa ingin tahu, semangat kebangsaan, cinta tanah air, menghargai prestasi, bersahabat/komunikatif, cinta damai,gemar membaca, peduli lingkungan, peduli sosial dan tanggung jawab. Nilai-nilai tersebut sudah mulai dilaksanakan sejak tahun ajaran 2001 seluruh tingkat pendidikan di Indonesia yaitu dengan memasukkan pendidikan karakter ke dalam materi pelajaran.

Menurut Khan nilai-nilai yang terkandung pendidikan karakter adalah nilai religius, nasionalis, cerdas, tanggung jawab, disiplin, mandiri, jujur, arif, hormat, santun, dermawan, suka menolong, gotong royong, percaya diri kerja keras, tangguh, kreatif, kepemimpinan, demokratis, rendah hati toleransi, solidaritas dan peduli. ${ }^{23}$

${ }^{23}$ Yahya Khan, Pendidikan Karakter Berbasis Potensi Diri, (Yogyakarta: Pelangi Publishing, 2010), hal. 34 . 
Nilai pendidikan karakter tersebut merupakan nilai dasar yang menjadi pola asuh yang semestinya dilaksanakan dari awal perkembangan kehidupan. Thomas Lickona memberikan nilai-nilai pendidikan karakter tersebut berdasarkan nilai-nilai luhur yang selama ini selalu diterapkan yaitu kecintaan akan Tuhan dan makhluk-Nya, kemandirian dan tanggung jawab, kejujuran, hormat dan santun, dermawan, percaya diri, adil, rendah hati dan memiliki jiwa damai dan toleransi. ${ }^{24}$

Michele Barba dalam buku Membangun Kecerdasan Moral ${ }^{25}$ Dalam buku tersebut dijelaskan pendidikan karakter atau kecerdasan moral harus memiliki nilai-nilai sebagai rujukan. Pertama nilai empati. Ini merupakan nilai dasar bagi perkembangan karakter anak untuk dapat memahami perasaan orang lain. Empati dapat menanamkan rasa peka terhadap kebutuhan sehingga mampu memberikan dan merasakan apa yang dirasakan orang lain sehingga terhindar untuk melukai orang lain baik dengan perasaan, berbicara maupun tindakan. Kedua nilai hati nurani. Nilai ini menjadi penting karena menjadi fondasi seseorang untuk berbuat jujur, bertanggung jawab dan memiliki integritas tinggi. Dengan hati nurani yang dimiliki seseorang akan selalu cenderung untuk melakukan hal-hal positif dan membentengi dari perbuatan tidak baik. Karena dengan hati nurani tersebut seseorang akan gelisah ketika melakukan perbuatan buruk. Ketiga nilai kontrol diri. Nilai ini akan menahan dorongan dalam diri seseorang untuk berfikir sebelum bertindak sehingga kemungkinan melakukan perbuatan tidak baik akan sedikit. Selain itu kontrol diri akan menanamkan sifat mandiri dalam diri seseorang, karena dengan kontrol diri seseorang harus bertanggung jawab untuk mengendalikan tindakan dan berupaya untuk melakukan tindakan yang baik. Keempat nilai rasa hormat. Penanaman rasa hormat yang diterapkan sejak dini akan menjadikan seseorang menghargai orang lain dan menghargai perbuatan orang lain serta akan memperlakukan orang lain sebagaimana memperlakukan diri sendiri sehingga meminimalisir rasa permusuhan, ketidakadilan, dan bertindak kasar. Kelima nilai kebaikan hati. Nilai ini akan menunjukkan kepedulian terhadap kesejahteraan dan perasan orang lain. Menimbulkan rasa kasih sayang dan tidak selalu memikirkan diri sendiri dan membangun sikap kebersamaan dan gotong royong. Keenam nilai toleransi. Nilai ini akan membentuk seseorang untuk menghargai orang lain, baik karena perbedaan gender, suku bangsa, bahasa, agama, kemampuan. Sikap ini akan memperlakukan orang lain, baik menghargai dan pengertian, sehingga terhindar dari sikap permusuhan, fanatisme berlebihan dan anarkis. Ketujuh nilai keadilan. Sikap ini akan mendorong seseorang untuk berlaku adil, membela memperlakukan pihak yang

\footnotetext{
${ }^{24}$ Thomas Lickona, Educating For Character: How Our School Can Teach Respect and Responsibility, New York: Bantam Books, 1992, hal. 12-22.

${ }^{25}$ Michelle Barba, Membangun Kecerdasan Moral,hal. 7-8.
} 
diperlakukan secara tidak adil dan memperlakukan orang lain setara tanpa melihat perbedaan suku, bahasa, budaya, gender dan agama.

Jika diamati berdasarkan nilai-nilai pendidikan karakter tersebut di atas, berbagai pandangan tokoh memberikan pandangan yang sama terhadap nilai-nilai pendidikan karakter. Nilai-nilai pendidikan karakter akan dapat tertanam dan diaplikasikan dalam kehidupan bermasyarakat jika seluruh komponen lembaga dan masyarakat berupaya untuk menjadikan pendidikan karakter sebagai sentral dalam mendidik anak-anak. Ibnu Miskawaih ${ }^{26}$ menjelaskan bahwa pendidikan karakter akan tertanam jika sikap yang terdapat dalam nilai pendidikan tersebut tertanam kuat menjadi kepribadian, hal ini tentu saja memerlukan waktu dan pembiasaan yang kontinu, hal lain untuk menciptakan nilai-nilai tersebut adalah menjadi perilaku pembiasaan sehingga dengan mudah dan tanpa pertimbangan seseorang berkarakter dengan baik, dan yang paling penting dari upaya penanaman pendidikan karakter adalah setiap perilaku dan nilai-nilai yang dilaksanakan tanpa paksaan dan dengan kesadaran sendiri melakukan hal tersebut. Selanjutnya adalah niali-nilai yang dilaksanakan dalam kehidupan tersebut tidak dibuat-buat atau perilaku tersebut apa adanya, sebagaimana pengertian moral atau akhlak yang menjelaskan bahwa perilaku yang spontan tanpa rekayasa. Yang tidak kalah penting dalam penanaman karakter (akhlak) menurut Ibnu Miskawaih adalah adanya motivasi keimanan yang kuat bahwa setiap perilaku diyakini akan dipertanggung jawabkan dan disaksikan Allah SWT.

\section{Anak Dalam Perspektif Al-Qur'an}

Menurut Abdul Razaq Husain menjelaskan bahwa anak merupakan amanah bagi orang tua yang harus dijaga dengan baik dan hak anak merupakan kewajiban bagi orang tua yang harus dilaksanakan sebagaimana yang telah digariskan dalam ajaran Islam yang berasal Al-Qur'an dan hadits. ${ }^{27}$ Anak merupakan dambaan setiap pasangan suami dan isteri. Memiliki anak menjadi salah satu kebanggaan karena akan menjadi regenerasi bagi orangtua. Berbagai upaya dan usaha dilakukan untuk mendapatkan buah hati. Perjuangan orang tua untuk mendapatkan anak-anak tidak sampai di situ saja, setelah mendapatkan anak, orang tua juga berupaya untuk memberikan yang terbaik untuk putra-putrinya baik itu yang berkaitan dengan sandang, pangan, papan, kesehatan, pendidikan dan lainnya untuk menghantarkan kebahagiaan bagi buah hatinya.

${ }^{26}$ Ibn Miskawaih, Tahzib al-Akhlaq wa Tathhir al-Araq (Mesir:al-Mathba’ah al-Misriyat, 1934), cet-1 hal. 40.

${ }^{27}$ Abdul Razaq Husain, Hak-hak Anak dalam Islam diterjemahkan oleh Azwir Butan dengan judul buku Islam wa Tiflu, Jakarta: Fika Hati Aniska, 1992 hal. 49. 
Dalam Al-Qur'an terdapat berbagai nama lain dari anak sebagaimana yang dijelaskan oleh Muhammad Baqi Fuad Abdul Baqi yaitu, zuriyyah (anak, cucu keturunan), ibn (anak atau orang), walad (anak-anak), Athfal (anak kecil), Shabiy (kanak-kanak), asbath (anak, cucu), aqrab (ana,cucu dan turunan kebawahnya),ghulam (anak muda), Nashl (keturunan), rabaib (anak tiri), ad'iya'akum (anak angkat). ${ }^{28}$

Berbagai panggilan nama yang dijelaskan Al-Qur'an menunjukan bahwa pembahasan mengenai anak sangat beragam disesuaikan dengan tingkatan usia anak. Selain panggilan, Al-Qur;an juga memberikan kedudukan kepada anak dengan berbagai keterangan. Pertama, anak diumpamakan sebagai perhiasan yang diharapkan dan selalu dijaga untuk dijadikan kebanggaan. Isyarat mengenai perhiasan ini sebagaimana tertera dalam Al-Qur’an Surat al-Kahfi [18] 46:

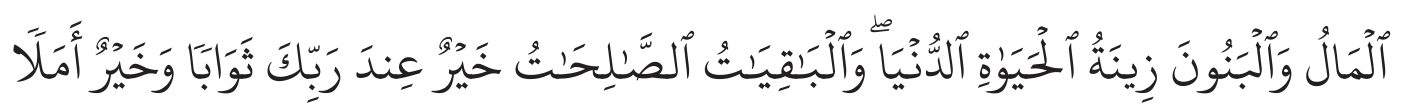

"Harta dan anak-anak adalah perhiasan kehidupan dunia tetapi amalan-amalan yang kekal lagi saleh adalah lebih baik pahalanya di sisi Tuhanmu serta lebih baik untuk menjadi harapan”. (QS al-Kahfi [18] 46).

Dalam tafsir al-Misbah dijelaskan bahwa harta dan anak-anak sebagai zinah (perhiasan) atau sesuatu yang dianggap baik dan indah, karena dalam harta dan anak-anak mengandung unsur keindahan disamping juga mengandung manfaat dan seorang anak dapat membantu dan membela kedua orang tuanya. ${ }^{29}$ Perhiasan yang dimaksud adalah kebanggaan orang tua akan prestasi dan keberhasilan setiap anak yang dapat mengharumkan orang tua. Akan tetapi untuk menciptakan anak sebagai perhiasan dibutuhkan kerjasana dan kerja keras dari orang tua untuk senantiasa memberikan tauladan dan pendidikan yang baik yang dapat menghasilkan karakter positif kepada anak-anak. Karena jika tidak ditopang dengan tauladan, pendidikan dan doa dari orang tua, upaya menghantarkan anak-anak sebagai perhiasan akan sulit terwujud.

Al-Qur'an memberikan contoh melalui kisah-kisah mengenai pentingnya peran orang tua dalam memberikan tauladan. Dari kalangan Nabi upaya tersebut dicontohkan oleh Nabi Ibrahim yang memegang teguh prinsip tauhid dan mempraktekan langsung bersama keluarga sehingga menghasilkan Ismail

${ }^{28}$ Muhammad Fuad Abdul Baqi: al-mu'jam al-mufahras li Alfaz Al-Qur'an al-karim, (Beirut: Daar al-Fikr li at-Tib’ah wa an- Nasyr wa at-Tauzu'), 1980, hal.270-699.

${ }^{29}$ Penamaan keduanya sebagai perhiasan (zinah) jauh lebih tepat daripada menamainya sesuatu yang berharga (qimah), karena kemuliaan dan penghargaan hanya dapat diperoleh dengan cara beriman dan beramal sholeh. Quraish Shihab, Tafsir al-Mishbah: Pesan dan Keserasian AlQur'an (Jakarta: Lentera Hati, 2004), vol ii, hal. 70. 
dan Ishak sebagai Rasul. Begitu juga dengan sosok Ali Imran dan Lukmanul Hakim yang namanya diabadikan dalam Al-Qur'an sebagai seorang figur ayah yang memberikan tauladan dan bekal pendidikan tauhid dan karakter yang menjadi referensi bagi orang tua.

Selain menjadi perhiasaan, keberadaan anak tidak jarang menjadi masalah untuk orang tua. Berbagai perilaku negatif seperti bolos sekolah, tawuran, berbohong, mencuri bahkan perilaku penyalahgunaan narkoba dan seks bebas menjadi masalah pelik orang tua. Keberadaan anak seperti ini menjadi fitnah bagi orang tua. Isyarat tersebut tertera dalam Al-Qur'an Surat al-Anfal [8] 28:

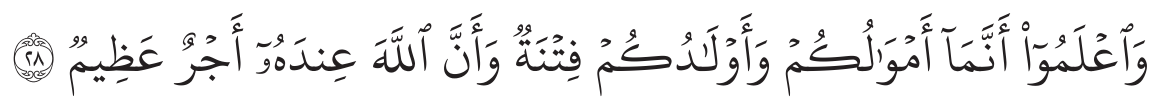

"Dan ketahuilah harta dan anak-anakmu itu hanyalah sebagai cobaan dan sesungguhnya di sisi Allah ada pahala yang besar. (QS al-Anfal [8] 28).

Dalam tafsir at-Tabhari dijelaskan bahwa kata fitnah adalah cobaan, yaitu cobaan yang diberikan kepada manusia baik dalam bentuk harta maupun anak. Abu jafar menjelaskan bahwa harta dan anak-anak adalah ujian yang Allah berikan untuk melihat bagaimana manusia yang beriman melaksanakan haknya kepada Allah. ${ }^{30}$ Untuk itu ketika menyaksikan keadaan anak-anak dengan kondisi tersebut hendakah orang tua bersabar dan berintropeksi diri juga perbanyak berdoa mendekatkan diri mengharapkan hidayah hadir untuk sang buah hati.

Selain faktor hidayah, kegagalan orang tua dalam mendidik anak-anak dapat menyebabkan juga anak menjadi musuh yang dapat menjerumuskan orang tua untuk melakukan perbuatan yang tidak diridhoi Allah SWT. Hal ini sebagaimana isyaratAllah dalam Al-Qur'an Surat at-Taghabun (4)14:

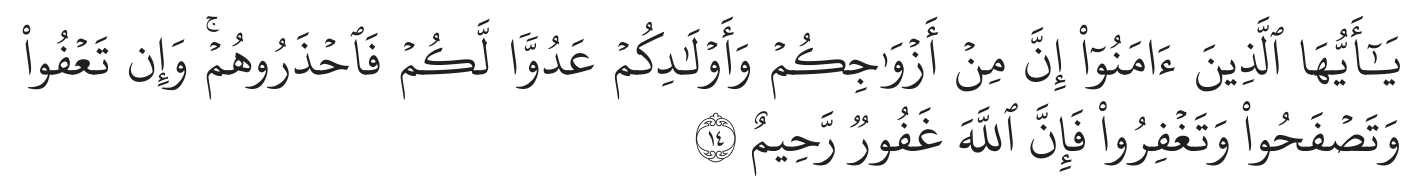

Wahai orang-orang yang beriman! Sesungguhnya di antar aistri-istrimu dan anak-anakmu ada yang menjadi musuh bagimu, maka behati-hatilah kamu terhadap mereka; dan jika kamu memaafkan dan kamu santuni serta ampuni (mereka), maka sungguh, Allah Maha Pengampun, Maha Penyayang. (QS al-Taghabun [64] 14)

\footnotetext{
${ }^{30}$ Abu Ja'far Muhamad bin Jarir Ath-Thabari, Tafsir Ash-Thabari, penerjemah Abdul Somad dkk, dengan judul buku jami' al-Bayan an Ta’wil Ayi Al-Qur'an, Jakarta: Pustaka Azzam, 2009, hal. 203-204.
} 
Isyarat dalam ayat tersebut ditampakkan melalui perseteruan orang tua dan anak karena pernikahan dimana pilihan anak dan orang tua yang tidak sesuai yang menyebabkan anak memaksakan kehendaknya dan membenci orang tua. Atau perilaku lain karena pembagian warisan, dimana orang tua mewariskan harta kepada anak-anaknya, yang menyebabkan anak-anaknya berseteru bahkan beberapa kasus orang tuanya dibunuh karena perebutan warisan tersebut. Untuk itu Allah SWT senantiasa selalu mengingatkan manusia untuk selalu menjaga diri sendiri dan menjaga ahli keluarga dan kerabat dari hal-hal yang dapat menjerumuskan ke dalam api neraka ${ }^{31}$ dengan cara bertaqwa kepada Allah SWT dan menjauhi larangannya juga mengawasi dan membantu keluarga (ahli) agar selalu berada di jalan Allah. Jika melihat ada penyimpangan hendaklah luruskan dan cegahlah dari perbuatan itu. ${ }^{32}$

Untuk itu kewajiban orang tua tidak hanya mencukupi dan memenuhi kebutuhan yang bersifat jasmaniah, akan tetapi penting juga untuk memberikan asupan rohaniah (spiritual) sehingga kehadiran anak-anak dapat menjadi qurata a'yun (penyejuk mata) ${ }^{33}$ yang dapat menghantarkan kebahagiaan di dunia dan akhirat.

\section{E. Pendidikan Karakter Anak Berbasis Al-Qur'an}

Dalam The Journal of Moral Educational volume 36 tahun 2007 secara khusus menjelaskan mengenai spiritualitas dan nilai-nilai agama yang tidak bisa dipisahkan dari pendidikan karakter. Dimana dalam ajaran Islam seluruh aspek disiplin ilmu dan tatanan kehidupan selalu berkaitan dengan pendidikan karak-

${ }^{31}$ Hai orang-orang yang beriman, peliharalah dirimu dan keluargamu dari api neraka yang bahan bakarnya adalah manusia dan batu; penjaganya malaikat-malaikat yang kasar, keras dan tidak mendurhakai Allah terhadap apa yang diperintahkan-Nya kepada mereka dan selalu mengerjakan apa yang diperintahkan.(QS. At-Tahrim/66: 7) Departemen Agama RI, Al-Qur'anul Karim, Jakarta: Badan Pentashih dan Penterjemah Departemen Agama RI, 2007.

${ }^{32}$ Abu Ja'far Muhamad bin Jarir Ath-Thabari, Tafsir Ash-Thabari, penerjemah Abdul Somad dkk, dengan judul buku jami' al-Bayan an Ta'wil Ayi Al-Qur'an, Jakarta: Pustaka Azzam, 2009, hal. 246.

${ }^{33}$... "Ya Tuhan Kami, anugerahkanlah kepada kami pasangan kami dan keturunan kami sebagai penyenang hati (kami), dan jadikanlah kami pemimpin bagi orang-orang yang bertaqwa. (QS. Al-Furqan/25: 74). Ibnu Katsir menjelaskan qaratu a'yun sebagai anak keturunan yang patuh dan taat beribadah kepada Allah. Sedangkan menurut pandangan Ibnu Abbas makna qurata a'yun adalah keluarga yang dapat menyenangkan pandangan mata di dunia dan di akhirat karena menjalankan ketaatan kepada Allah SWT. Hal senada juga disampaikan oleh Hasan al-Bashri yang mengatakan bahwa tidak ada yang lebih menyejukkan mata selain dari keberadaan anak keturunan yang soleh dan taat yang merupakan karunia sekaligus amanah dan sumber kebahagiaan yang diberikan oleh Allah SWT. Ridwan Abdul Sani dan Muhammad Kadri, Pendidikan Karakter: Mengembangkan Karakter Anak yang Islami (Jakarta: Bumi Aksara, 2016), hal. 191. 
ter. ${ }^{34}$ Pentingnya pendidikan karakter yang ditanamkan sejak dini merupakan proses pembelajaran yang dapat memudahkan anak untuk bersikap terpuji dan dapat berinteraksi dengan baik.

Selain itu terdapat kewajiban utama orang tua untuk memberikan kebahagiaan dan kesejahteraan untuk anak-anak agar mereka tumbuh dan hidup bahagia agar kelak dewasa anak-anak dapat mandiri dan berkontribusi untuk kepentingan umat. Isyarat tersebut Allah jelaskan dalam Al-Qur'an Surat an-Nisa [4] 9:

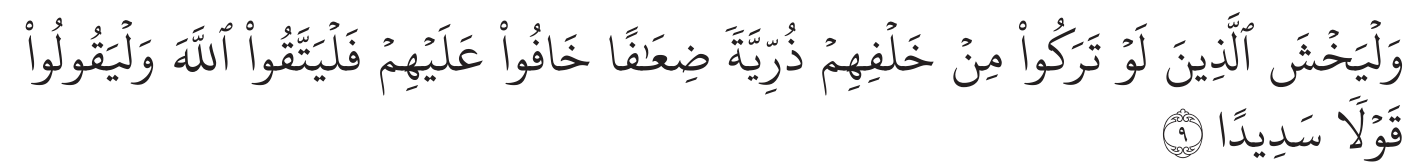

Dan hendaklah takut kepada Allah orang-orang yang seandainya meninggalkan di belakang mereka anak-anak yang lemah, yang mereka khawatir terhadap (kesejahteraan)mereka. Oleh sebab itu hendaklah mereka bertakwa kepada Allah dan hendaklah mereka mengucapkan perkataan yang benar. (QS al-Nisa [4] 9).

Dalam ayat tersebut dijelaskan bahwa pentingnya setiap orang tua mempersiapkan anak-anak mereka bekal yang dapat memberikan kesejahteraan baik di dunia maupun di akhirat. Selain itu dijelaskan pula orang tua diperintahkan untuk mendidik anak-anak dengan pendidikan taqwa dan mencontohkan perkataan yang benar.

Selain memberikan perintah untuk memperlakukan anak-anak dengan baik, Al-Qur'an juga telah memberikan contoh teladan bagi orang tua dalam mendidik anak-anak sebagaimana yang dicontohkan oleh Luqmanul Hakim. Nama Luqmanul Hakim diabadikan dalam Al-Qur'an menjadi figur dalam mendidik anak karena proses pembelajaran dan metode yang diberikan dengan cara hikmah. Hikmah menurut Quraish Shihab ${ }^{35}$ adalah segala sesuatu jika digunakan atau diperhatikan akan mendatangkan kemaslahatan dan kemudahan yang besar atau lebih besar, serta menghalangi terjadinya madharat atau kesulitan yang besar atau lebih besar.

${ }^{34}$ Pendidikan karakter ( akhlak) menjadi sangat penting karena diutusnya Rasulullah adalah untuk memperbaiki akhlak yang utama dan pertama. Begitu pentignya penanaman karakter positif ini karena akin mempengaruhi pola ibadah dan hubungan muamalah setiap manusia. Abdul Madjid dan Dian Andayani, Pendidikan Karakter Perspektif Islam, Jakarta: Remaja Rosdakarya, 2011, hal.58.

${ }^{35}$ Quraish M. Shihab, Tafsir al-Misbah: Pesan, Kesan, dan Keserasian Al-Qur'an, (Jakarta: Lentera Hati, 2002), hal. 386. 
Menurut Armai Arif yang dikutip oleh Akhmad Alim menjelaskan bahwa hikmah dapat ditafsirkan sebagai kemampuan berfikir, pemahaman yang sempurna dan kesederhanaan. Ada yang berpendapat sebagai akal pikiran. Paham, ucapan yang benar, mengetahui berbagai hal dan melaksanakan kebaikan sehingga sesuai antara amal dan ilmu yang dimiliki. ${ }^{36}$ Pendidikan dan pengajaran dengan pendekatan hikmah adalah pendekatan yang dilakukan dengan cara keteladanan, praktek, dan amtsal (perumpamaan) dimana orang tua terlibat langsung dalam proses pembentukan kepribadian dan karakter anak-anak bahkan sikap, perkataan dan perbuatan orang tua akan menjadi contoh langsung untuk pendidikan anak-anak.

Pola pendidikan yang dikembangkan Lukmanul Hakim kepada putranya Allah abadikan dalam Al-Qur'an Surat Luqman [31] 13-19. ${ }^{37}$ Dalam kandungan ayat tersebut Luqman memberikan pendidikan pertama dan utama yaitu tentang tauhid, dimana dijelaskan bahwa:

.... "Hai anakku, janganlah engkau mempersekutukan Allah sesungguhnya mempersekutukannya (Allah) adalah benar-benar kedzaliman yang besar.

Pendidikan ketauhidan yang diberikan Luqman adalah upaya memperkenalkan kepada putranya tentag siapa penciptanya. Hal ini penting dilakukan

${ }^{36}$ Akhmad Alim, Tafsir Pendidikan Islam (Jakarta: AMP Press, 2014), hal. 137.

${ }^{37}$ Dan (ingatlah) ketika Luqman berkata kepada anaknya, di waktu ia memberi pelajaran kepadanya: "Hai anakku, janganlah kamu mempersekutukan Allah, sesungguhnya mempersekutukan (Allah) adalah benar-benar kezaliman yang besar".

Dan Kami perintahkan kepada manusia (berbuat baik) kepada dua orang ibu-bapaknya; ibunya telah mengandungnya dalam keadaan lemah yang bertambah-tambah, dan menyapihnya dalam dua tahun. Bersyukurlah kepada-Ku dan kepada dua orang ibu bapakmu, hanya kepada-Kulah kembalimu

Dan jika keduanya memaksamu untuk mempersekutukan dengan Aku sesuatu yang tidak ada pengetahuanmu tentang itu, maka janganlah kamu mengikuti keduanya, dan pergaulilah keduanya di dunia dengan baik, dan ikutilah jalan orang yang kembali kepada-Ku, kemudian hanya kepada-Kulah kembalimu, maka Kuberitakan kepadamu apa yang telah kamu kerjakan

(Luqman berkata): "Hai anakku, sesungguhnya jika ada (sesuatu perbuatan) seberat biji sawi, dan berada dalam batu atau di langit atau di dalam bumi, niscaya Allah akan mendatangkannya (membalasinya). Sesungguhnya Allah Maha Halus lagi Maha Mengetahui

Hai anakku, dirikanlah shalat dan suruhlah (manusia) mengerjakan yang baik dan cegahlah (mereka) dari perbuatan yang mungkar dan bersabarlah terhadap apa yang menimpa kamu. Sesungguhnya yang demikian itu termasuk hal-hal yang diwajibkan (oleh Allah)

Dan janganlah kamu memalingkan mukamu dari manusia (karena sombong) dan janganlah kamu berjalan di muka bumi dengan angkuh. Sesungguhnya Allah tidak menyukai orang-orang yang sombong lagi membanggakan diri

Dan sederhanalah kamu dalam berjalan dan lunakkanlah suaramu. Sesungguhnya seburukburuk suara ialah suara keledai 
agar kelak ketika anak sukses akan selalu ingat bahwa kesuksesan dan keberhasilan bukan hanya kerja kerasnya saja akan tetapi berasal dari Allah SWT. Begitu juga jika anak-anak mengalami kegagalan dan kehancuran, anak tidak cepat putus asa dan melakukan perbuatan yang tidak diharapkan akan tetapi anak akan meyadari bahwa Allah akan selalu hadir untuk memberikan kekuatan.

Penulis berpendapat bahwa pendidikan tauhid ini akan mencerminkan karakter pengabdian yang kuat yang tertanam dalam diri anak, sehingga akan menciptakan karakter setia, taat, tawadhu, dan tawakal serta akan tetap tertanam sikap kuat bahwa Allah Yang Maha Mengawasi.

Setelah pendidikan ketauhidan, Luqmanul Hakim menjelaskan pentingnya pendidikan akhlak, dalam ayat ke 14-15 dijelaskan bahwa keharusan berkata dan berbuat baik kepada orang tua meskipun orang tua mengajak kepada kekufuran. Hal ini dikarenakan pengorbanan orang tua yaitu ibu yang telah mengandung, menyusui, dalam keadaan payah dan lemah. As-Samarqandi menjelaskan bahwa kata "wahnan" bermakna kelemahan atau kerapuhan di atas semua hal, yakni segala hal yang berkaitan dengan kelemahan menyatu dan dirasakan ibu. ${ }^{38}$

Karakter yang dibangun dalam ayat tersebut adalah rasa syukur dan berterima kasih kepada orang tua yang telah bersusah payah mengandung, melahirkan dan membesarkan putra-putrinya. Selain itu ayat ini juga mengajarkan sikap menghargai dan toleransi terhadap perbedaan baik itu yang berkaitan dengan ibadah maupun hubungan sosial yang dapat dikembangkan pada ranah yang lebih luas selain anggota keluarga.

Pendidikan Lukmanul Hakim selanjutnya adalah mengenai ibadah. Perintah shalat yang dijelaskan ayat 17 mengisyaratkan bahwa menegakkan shalat dapat melakukan perubahan spiritual, memperkuat kepribadian dan meneguhkan hubungan dengan Allah agar lisan, hati dan seluruh anggota badan selalu berada dalam lindungan Allah sehingga tercipta keshalehan individu. ${ }^{39}$ Selain itu karakter yang terdapat dalam pelaksanaaan sholat dapat memupuk sifat istiqamah dan disiplin dalam melaksanakan kegiatan sehari-hari juga sikap taat terhadap pimpinan.

Selain itu kandungan ayat 17 ini Lukmanul Hakim mengajarkan kepada anak pentingnya melakukan hubungan sosial atau berbuat baik dan bersosialisasi dengan lingkungan yaitu dengan cara mengajak kepada kebaikan dan mencegah kemungkaran. Upaya ini adalah wujud dari keberadaan manusia sebagai makhluk sosial, sehingga karakter yang dibangun adalah terbentuknya

\footnotetext{
${ }^{38}$ As-Samarqandi, Bahr al-Ulum (Beirut: Dar al-Fikr, t.tp)J, vol 3, hal. 23.

${ }^{39}$ Akhmad Alim, Tafsir Pendidikan Islam, hal. 77.
} 
kesalehan sosial. Karakter saleh sosial ini akan menciptakan lingkungan yang baik, aman karena setiap orang yang terlibat dalam lingkungan tersebut saling mengingatkan dan membantu sehingga tercipta lingkungan yang dirahmati.

Selanjutnya pesan Lukman pada ayat ke 18 adalah tazkiyatunnafs. ${ }^{40}$ Dalam ayat ini Lukman memerintahkan putranya untuk tidak memalimgkan muka, berlaku sombong, berjalan angkuh karena perbuatan tersebut merupakan karakter negatif yang akan memberikan kehancuran kepada diri sendiri.

Sikap yang dibangun Lukmanul Hakim dalam mendidik anak sangat dibutuhkan saat ini dimana dengan bekal tauhid yang kuat, ibadah yang rajin, hubungan sosial yang baik juga perilaku yang ramah dan mendamaikan akan memberikan angin segar bagi upaya perbaikan karakter.

Pembentukan karakter juga termanivestasikan dalam ketauladanan Rasulullah Muhammad SAW melalui empat karakter. Pertama, Sidiq yang diartikan benar berbicara, bertindak dan bersikap. Kedua amanah adalah terpercaya baik ucapan dan perilaku, ketiga Tabligh artinya akuntabel atau meny ampaikan dengan baik dan professional, keempat Fathonah artinya cerdas, yang dimaksud cerdas disini tidak hanya cerdas secara intelektual akan tetapi mampu mengendalikan emosi dan menjadikan dirinya penyelesai masalah dalam permasalahan pribadi dan berbagai permasalahan umat. Selain itu Rasulullah mampu melewati berbagai permasalahn hidup dengan penuh kesabaran, ketenangan dan keikhlasan. Ketahanmalangan Rasulullah dalam menghadapi situasi dan kondisi merupakan pijakan awal bagi seorang pemimpin umat yang dapat melewati rintangan dengan menyelesaikan masalah secara bijak dan menjadikan lawan sebagai kawan. Sikap demikian ini merupakan pendidikan karakter yang terbangun dengan baik dan terbiasa sehingga mampu mengendalikan berbagai kendala dan permasalahan yang berhubungan dengan keadaan sosial. Selain itu sifat empati yang terbangun dalam diri Rasulullah menjadikan setiap lawan dari berbagai kalangan menjadikan Rasulullah sebagai tauladan sepanjang zaman.

Dengan berlandaskan Al-Qur'an dan hadits, pendidikan karakter yang dibangun dapat menghantarkan anak-anak cerdas intelektual, cerdas emosional dan sholeh spiritual, sehingga dapat menghantarkan tidak hanya soleh secara individu akan tetapi dapat menciptakan soleh secara sosial dan menjadikan negara yang bahagia dan diridhoi Allah SWT.

\section{F. Kesimpulan}

Pendidikan karakter yang diberikan kepada anak-anak sejak dini dapat menciptakan kepribadian dan pembiasaan yang dapat menjadikan anak-anak

${ }^{40}$ Akhmad Alim, Tafsir Pendidikan Islam, hal.81. 
tumbuh menjadi pribadi yang soleh secara individu dan soleh secara sosial. Pedidikan tersebut dicontohkan oleh Lukmanul Hakim yang tertera dalam Surat Luqman/31: 13-19 yang menjelaskan bahwa setiap orang tua dan pendidik harus menjadi contoh, baik itu dalam perkataan, perbuatan dan sikap serta menanamkan pendidikan ketauhidan, akhlak, ibadah, hubungan sosial dan tadzkiyatunnafs kepada setiap anak sebagai dasar kurikulum yang dikembangkan dalam setiap pembelajaran dan aktifitas. Dengan harapan dapat menjadi solusi dari berbagai permasalahan yang dihadapi anak-anak. 


\section{Daftar Pustaka}

Alim, Akhmad. Tafsir Pendidikan Islam, Jakarta: AMP Press, 2014.

Albertus, Doni Koesoema, Pendidikan Karakter Strategi Mendidik Anak di Zaman Global, Jakarta: PT. Grasindo, 2010.

Al-Qur'anul Karim, Departemen Agama RI.

Ath-Thabari, Abu Ja'far Muhamad bin Jarir Tafsir Ash-Thabari Jakarta: Pustaka Azzam, 2009.

As-Samarqandi, Bahr al-Ulum, Beirut: Dar al-Fikr, Jilid 3.

Baqi, Muhammad Fuad Abdul. al-mu'jam al-mufahras li Alfaz Al-Qur'an al-karim, Beirut: Daar al-Fikr li at-Tib'ah wa an- Nasyr wa at-Tauzu', 1980.

Berba, Michele Membangun Kecerdasan Moral, Jakarta : Gramedia Pustaka Utama, 2008.

http://www.kpai.go.id/artikel/tawuran-pelajar-memprihatinkan-dunia-pendidikan/

http://www. tempo.co.id "Tawuran Sekolah Jakarta Naik44".

http://www.kpai.go.id/artikel/tawuran-pelajar-memprihatinkan-dunia-pendidikan/

Hasbullah, Dasar-dasar Ilmu Pendidikan, Jakarta: RajaGrafindo, 2001.

Husain, Abdul Razaq. Hak-hak Anak dalam Islam Jakarta: Fika Hati Aniska, 1992.

Khan, Yahya. Pendidikan Karakter Berbasis Potensi Diri: Mendongkrak Kualitas Pendidikan, Yogyakarta: Pelangi Publishing, 2010.

Kesuma, Dharmawan. Pendidikan Karakter Kajian Teori dan Praktik Di Sekolah, Bandung: Remaja Rosdakarya, 2013.

Lickona, Thomas. Educating For Character: How Our School Can Teach Respect and Responsibility, New York: Bantam Books, 1992.

Madjid, Abdul. Dian Andayani. Pendidikan Karakter Perspektif Islam, Jakarta: Remaja Rosdakarya, 2011

Mulyasana, Dedi. Pendidikan Bermutu dan Berdaya Saing, Bandung: Remaja Rosdakarya, 2012.

Miskawaih, Ibn. Tahzib al-Akhlaq wa Tathhir al-Araq, Mesir: al-Mathba’ah al-Misriyat, 1934.

Nata, Abuddin. Pendidikan dalam Perspektif Al-Qur'an, Jakarta: UIN Jakarta Press, 2005.

Sani, Ridwan Abdul dan Muhammad Kadri, Pendidikan Karakter: Mengembangkan Karakter Anak yang Islami, Jakarta: Bumi Aksara, 2016.

Shihab, Quraish M. Tafsir al-Misbah: Pesan, Kesan, dan Keserasian Al-Quran, Jakarta: Lentera Hati, 2002. 
Sudarto, Wacana Islam Progresif, Jogyakarta : IRCiSoD, 2014.

Soyomukti, Nurani. Teori-teori Pendidikan, Yogyakarta: Ar-Ruzz Media, 2011

Syarbini, Amirullah. Buku Pintar Pendidikan Karakter: Panduan Lengkap Mendidik Karakter Anak di Sekolah, Madrasah dan Rumah, Jakarta: as-Prima Pustaka, 2012.

Tafsir, Ahmad. Pendidikan Karakter Perspektif Islam, Jakarta: Remaja Rosda Karya, 2011.

Winkel, W.S. Psikologi Pengajaran, Jakarta: Gramedia, 1987.

Zubaedi, Desain Pendidikan Karakter: Konsepsi dan Aplikasinya dalam Lembaga Pendidikan, Jakarta: Kencana, 2011. 
74 Mumtäz Vol. 1 No. 1, Tahun 2017 